\title{
Project-based Learning for Environmental Sustainability Action
}

Sharon Bramwell-Lalor, Therese Ferguson, Carol Hordatt Gentles, Carmel Roofe, University of the West Indies, Jamaica, and Keith Kelly, TrashedWorld

\begin{abstract}
The quest for social and economic development coupled with a growing population has led to complex and unsustainable interactions between humans and the natural resources of planet Earth. One approach to addressing complex, 'wicked' problems involves closing the gap between the sustainability knowledge of individuals and the competencies for positive environmental behaviours. Projectbased learning is one teaching-learning strategy which provides opportunities for cultivating a wide range of sustainability competencies to close this gap. Two cases are presented in this paper in which project-based learning was used for fostering environmental competencies and advancing sustainability. One relates to teachers in a graduate course, and the other, to students using an online learning platform. Evaluation of various qualitative documents and artefacts produced by participants revealed that i) teachers and students were motivated and enabled to take action on environmental and sustainability issues through project-based learning ii) participants' environmental knowledge and sustainability competencies such as communication and collaboration skills were enhanced. School administrators should therefore encourage a culture where project-based learning is infused into the curriculum, and teachers' collaborative efforts regarding projects are supported.
\end{abstract}

Keywords: project-based learning, education for sustainable development, teacher preparation, online learning platform

\section{Introduction}

A number of today's sustainability challenges can be characterised as 'wicked' problems that are "highly resistant to resolution" (Australian Public Service Commission, 2007, p. 3). These problems include a range of issues such as obesity, land degradation, and, of course, climate change (Australian Public Service Commission, 2007). These and other wicked problems have the potential to "threaten at least the standard of living for most of the people around the globe, and possibly the survival of the species" (Jones \& Akura, 2017, p. 75). These issues are wicked in nature due to their distinguishing characteristics, which include: they are difficult to define, multi-causal in nature with interdependencies, socially complex, involve multiple stakeholders with contrasting views and have no definitive solution (Australian Public Service Commission, 2007; Krasny, 2013; Wright \& Monsour, 
2020). Given the nature of these problems, environmental scientists have proposed several approaches to addressing them including cross-disciplinary and participatory research and systems thinking (Krasny, 2013).

Traditional education, rooted in what Buckles (2018) referred to as the Modern Social Imaginary (akin to a modern worldview), can be seen as a contributor to these wicked problems given that it has promulgated the idea that the natural world is measurable, controllable, predictable, and subject to humans' manipulation. A different type of education is therefore needed to tackle these issues (Jones \& Akura, 2017). Leicht et al. (2018) proposed that "... in an increasingly complex and interconnected world with a very real existential threat such as climate change, there is a growing demand for education that goes beyond acquiring knowledge and skills to find jobs. It has become clear that education is not only an instrument for sustainable development but that the concept of teaching and learning must be transformed to enable individuals to lead sustainable development as agents of change" (p. 32). Education for Sustainable Development (ESD) offers considerable potential for addressing wicked problems given the pedagogies and competencies it embraces, such as systemic thinking, problem solving skills, authentic and real-world learning (Jones \& Akura, 2017; Leicht et al., 2018). Among its learning outcomes are collaborative decision-making, intergenerational perspectives, and action competencies (UNESCO, 2014).

Education for Sustainable Development "empowers learners to take informed decisions and responsible actions for environmental integrity, economic viability and a just society, for present and future generations, while respecting cultural diversity. It is about lifelong learning, and is an integral part of quality education. ESD is holistic and transformational education which addresses learning content and outcomes, pedagogy and the learning environment. It achieves its purpose by transforming society" (UNESCO, 2014, p. 12). Education for Sustainable Development is thought to be broader than environmental education being set "... in the broader context of socio-cultural factors and the socio-political issues of equity, poverty, democracy and quality of life..." (Gough, 2006, p. 2).

According to Gough (2006), the 'language' of sustainability emerged during the 1980s and 1990s through major global documents, entities, and forums such as the World Conservation Strategy, the World Commission on Environment and Development, and the United Nations Conference on Environment and Development (UNCED). Education's role within and for sustainability was also discussed and voiced during this time. Agenda 21, one of the major outcomes of the UNCED, outlined four main emphases of ESD, in Chapter 36, one of which was the reorientation of education towards sustainability. This reorientation involves "developing strategies to teach awareness, skills, perspectives, and values that will guide and motivate people to pursue sustainable livelihoods, participate in a democratic society, and live in a sustainable manner" (McKeown \& Hopkins, 2003, p. 120). Hume and Barry (2015, p. 733) proposed that ESD must be "interdisciplinary, action-orientated, and holistic and combine both cognitive and conative aspects, as well as integrating both ethical and political analyses". Further, it is important to note that, as voiced in Agenda 21, ESD must take place at all educational levels and in formal and non-formal education. Education for Sustainable Development has been promoted more recently through the Decade of Education for Sustainable Development 
(DESD), the Global Action Programme (GAP) on ESD, and the Sustainable Development Goals (SDGs), in particular SDG 4 and Target 4.7.

With increasingly pervasive threats of wicked problems, ESD's potential for addressing these at all educational levels is clear. In light of this, we explore Project-Based Learning $(\mathrm{PjBL})$ in this paper, highlighting how it can support ESD to foster competencies required for addressing wicked problems. We focus on two seemingly disparate examples drawn from Jamaica and Bulgaria, one of which focuses on teachers in a graduate course, and the other on students using an online learning platform.

There are many examples in the literature of studies on PjBL applied to sustainability. This paper, however, highlights PjBL in two country contexts - Jamaica and Bulgaria - that are not always in the forefront of ESD literature. The paper is guided by the following question: In what ways do these two case studies illustrate the use of project-based learning to promote competencies in support of environmental sustainability?

\section{Theoretical framework}

\section{Education for sustainable development competencies}

Considering the role of education in conveying the messages of sustainability to learners and empowering them to take an active part in creating sustainable societies, the United Nations Economic Commission for Europe (UNECE) proposed a strategy to "facilitate the introduction and promotion of education for sustainable development" (UNECE, 2005, p. 2) for member states. Among the actions targeted was to "develop the competence within the education sector to engage in ESD" (p. 10). This mandate might have contributed to considerable work being done in identifying and naming specific sustainability competencies.

There are varying interpretations of the term 'competencies' in different sectors and contexts. Lambrechts et al. (2013) indicated that competencies are sometimes equated with ESD knowledge, skills, and attitudes. Leicht et al. (2018), however, defined competencies as "the capacity or disposition to act to address complex challenges..." (p. 45). Wiek et al. (2016) offered a similar definition: "a functionally linked complex of knowledge, skills, and attitudes that enable successful task performance and problem solving” (p. 242). In all three definitions, specific elements must be present in order to address sustainability problems.

In trying to identify these specific elements, various frameworks have been proposed including: the Curriculum, Sustainable Development, Competences, Teacher Training (CSCT) framework (consisting of five competence domains) (Sleurs, 2008), the UNECE (2011) framework for teacher education (four clusters of competencies), and De Haan's (2006) Gestaltungskompetenz (shaping competence) framework of 12 competencies. Wiek et al. (2011, 2016), drawing on a variety of scholars, proposed a framework which has six competencies. Wiek et al.'s model also crafted learning outcomes in order to operationalise the competencies at different educational levels, a feature they argue has been missing from the literature.

The selected models, although different, have similar characteristics. Rieckmann (2018) presented these as a synthesis of competencies which includes all six from Wiek et al.'s 
framework and others, namely: systems thinking, being anticipatory (futures thinking), normative (values thinking), strategic (action oriented), collaboration (interpersonal skills), critical thinking, self-awareness and integrated problem-solving. In addition to these competencies, Rieckmann (2018) claimed that communication skills are critical for dealing with sustainable development. Generally, ESD competencies require futures thinking, an interdisciplinary approach, personal involvement (reflection, empathy, motivating self and others), and attention to values and ethics (Lambrechts et al., 2013).

\section{Project-based learning}

Education for Sustainable Development focuses on content related to 'wicked problems' which are complex in nature. A related consideration of the focus on ESD competencies is the question of how they can be acquired to enable successful solving of real-world issues. Lambrechts et al. (2013) identified three categories of teaching and learning methods suitable for ESD: they should be interactive and participative (e.g., group discussion and peer assessment), research oriented (e.g., problem analysis, values clarification) and action oriented (e.g., solving real community problems). Project-based learning has been named as an action oriented strategy suitable for ESD (Kilinc, 2010; Cloud, 2014; Lozano et al., 2015; Scott, 2015).

The Buck Institute of Education (as cited in English \& Kitsantas, 2013, p. 130) defined PjBL as a "...method that engages students in learning knowledge and skills through an extended inquiry process structured around complex, authentic (real-life) questions and carefully designed products and tasks". Bell (2010, p. 39) highlighted that PjBL is a critical strategy "for creating independent thinkers and learners. Children solve real-world problems by designing their own inquiries ... organizing their research, and implementing a multitude of strategies." These definitions suggest students are central in PjBL, actively self-regulating their learning, and connecting with their community (English \& Kitsantas, 2013; Stefanou et al., 2013).

One model of PjBL has identified the following necessary elements: a central question (open-ended, complex), student voice and choice (they select their own topic and resources for inquiry), opportunities to build 21st century skills (communication, collaboration, critical thinking, creativity and technology use) and findings publicly presented (e.g., to the community, parents, peers) (Larmer \& Mergendoller, 2010).

The benefits of $\mathrm{PjBL}$ include increased understanding of particular issues, motivation, independent thinking, responsibility, collaboration, communication and problem-solving skills (Bell, 2010; Duerden \& Witt, 2010; Tamin \& Grant, 2013 ; Genc, 2014). Some challenges to $\mathrm{PjBL}$ are also identified in the literature. These include lack of resources and administrative support, the time needed to transition to a facilitative teaching style and contending with completing curricula in exam-driven contexts (David, 2008; Saavedra \& Opfer, 2012; Tamin \& Grant, 2013; Malek, Hall, \& Hodges, 2014; Aitken, 2019).

The characteristics of $\mathrm{PjBL}$ are aligned with ESD competencies. For instance, strategic competencies (developing and implementing actions), collaboration (facilitating participatory problem solving, learning from others, dealing with group conflicts), critical thinking (questioning norms, practices and opinions) and integrated problem-solving competencies 
(applying problem-solving frameworks to complex problems and developing solutions) can be facilitated through PjBL.

Project-based learning and the concept of acquiring sustainability competencies are aligned with social constructivism in which learners construct knowledge through experiencing things, reflecting on those experiences and interacting with their peers for discussing, generating, and sharing information (Roessingh \& Chambers, 2011). Both are also aligned with the experiential learning theory where individuals' learning is linked to applying various skills to real-world problems. The experiential learning theory which draws on the work of John Dewey, Jean Piaget and others (Efstratia, 2014) simply proposes that individuals 'learn by doing'. This suggests that being immersed in relevant issues and reflecting on them will encourage development of new skills and actions.

There is a need for more research concerning pedagogical approaches related to ESD competencies (Laurie et al., 2016). This paper seeks to address this need by identifying the competencies linked to sustainability that were evident when PjBL was applied in different cultural contexts: a Higher Education Institution and an online platform for younger learners.

\section{Methodology}

To showcase the opportunities presented using PjBL to advance ESD activities, two case studies are presented in this paper. Case studies are important for providing a contextual analysis of a phenomenon or situation and for establishing patterns and extending relationships (Gomm, Hammersley \& Foster, 2000). As such this approach was deemed useful for highlighting the use of $\mathrm{PjBL}$ at two different levels of the education system.

The first case study highlights PjBL in an Environmental Education (EE) graduate-level teacher training course at a School of Education at a university in Jamaica, while the second case study showcases students at the K-12 level pursuing modules as investigations of the global impact of waste issues through an online learning platform called 'TrashedWorld' hosted in Bulgaria. Though these contexts are dissimilar, they are unified through a common purpose of creating a more sustainable world. Another difference between the cases is the host country context which provides opportunities for intercultural as well as cross-cultural analysis and insights.

Data was collected for Case Study One through the analysis of the course syllabus, projects produced by graduate students, reports on projects and students' course reflections. For Case Study Two, content on the online platform (TrashedWorld), module syllabi, lessons, products and reports from students' investigations, and feedback reports from their teachers were analysed. In both cases, participants' identities have not been revealed and the necessary protocols for access to materials were observed to ensure adherence to ethical considerations. 


\section{Results}

\section{Case One: Project-based learning in an environmental education course within a teacher preparation programme}

\section{Context}

The School of Education at the University of the West Indies (UWI) prepares educators for national and regional education systems and contributes to educational policy within the Caribbean (The UWI - School of Education, https://www. mona.uwi.edu/soe/aboutschool). The School of Education is well placed to prepare teachers in utilising appropriate pedagogical strategies to foster sustainability competencies. This paper provides an account of the 2016 offering of the semester-long environmental education course for science and non-science specialist in-service teachers. The major assessment task in the course involves formulating and implementing a project for addressing a local environmental problem. This is discussed in the first week of the course. It is a requirement to implement the project collaboratively within schools, homes or communities. At the end of the course the participants submit a report on the project implementation and outcomes. Teachers' experience of PjBL was analysed from pre-and post-course reflection documents as well as the project reports which also had a reflective component.

\section{Outcomes}

The teachers selected their focus issue by the third week of the course. Project formulation was assisted through discussion of articles in the course material, lectures on selected environmental and sustainable issues, and mentoring from the course lecturer who is one of the authors of this paper. The teachers designed and implemented projects in various settings such as homes, communities, workplaces and schools (see Table 1).

Table 1 Projects implemented by in-service teachers

\begin{tabular}{|c|l|}
\hline Teacher & Project theme \\
\hline $\mathbf{1}$ & Investigating water conservation by households in an urban community \\
\hline $\mathbf{2} \& \mathbf{3}$ & $\begin{array}{l}\text { Developing a whole-school approach towards becoming an eco-school in an inner } \\
\text { city community }\end{array}$ \\
\hline $\mathbf{4} \mathbf{\&} \mathbf{5}$ & Plastic bottle recycling at the workplace and in a community housing complex \\
\hline $\mathbf{6}$ & Improving paper use and disposal efficiency in a work-place \\
\hline $\mathbf{7}$ & $\begin{array}{l}\text { Implementing an environmental stewardship programme in a primary (elementary) } \\
\text { school }\end{array}$ \\
\hline $\mathbf{8}$ & Investigating household electricity consumption and energy conservation practices \\
\hline
\end{tabular}


Importantly, the project by Teacher 8 was conducted by students in their homes. Further, the data from that project provided content for classroom discussions (see Table 2), thus interlinking the school context with real-world experiences. These students had opportunities to gain knowledge and skills (e.g., collaboration, communication), and at the same time practise responsible, environmental and sustainable behaviours.

Table 2 Outline of an energy conservation project implemented by students in their homes

\begin{tabular}{|c|c|}
\hline Week & Activities \\
\hline 1 & $\begin{array}{l}\text { Teacher: } \\
\text { - Taught lesson on energy conservation methods and how to read electricity meters. } \\
\text { - Discussed project with students; distributed permission letters to take home for } \\
\text { participation in the project. } \\
\text { Students: } \\
\text { - Formed a social media communication group to remind each other to read their } \\
\text { meters on Sundays. } \\
\text { - Designed tables to record their meter readings. }\end{array}$ \\
\hline 2 & $\begin{array}{l}\text { Students: } \\
\text { - Read meters and record results. } \\
\text { Teacher: } \\
\text { - Checked students' readings on Monday. } \\
\text { - Discussed data. } \\
\text { - Re-taught meter-reading for two students who had forgotten how to but instead } \\
\text { had taken photographs of the meter readings. }\end{array}$ \\
\hline $3-5$ & $\begin{array}{l}\text { Students: } \\
\text { - Read meters and recorded results. } \\
\text { - Calculated the amount of electricity consumed over the period. } \\
\text { Teacher: } \\
\text { - Discussed five energy saving tips with students. } \\
\text { - Encouraged students to implement the tips at home. }\end{array}$ \\
\hline $6-9$ & $\begin{array}{l}\text { Students: } \\
\text { - Practised energy conservation tips along with family members. } \\
\text { - Continued to record meter readings. } \\
\text { Teacher: } \\
\text { - Discussed practices and challenges faced. }\end{array}$ \\
\hline 10 & $\begin{array}{l}\text { Students: } \\
\text { - Performed final calculations. } \\
\text { - Completed and returned questionnaire about their energy conservation practices } \\
\text { since initial electricity bill was received. } \\
\text { Teacher: } \\
\text { - Held final discussions about the class results. }\end{array}$ \\
\hline
\end{tabular}


Teachers and students were motivated to take action through the PjBL approach. One teacher, reflecting on her paper recycling project, wrote "I have developed a greater appreciation of trees and their place in our environment. It has inspired me to address the issues of the environment in particular deforestation" (Teacher 6, Post-course reflection document, May 2016). It was reported that students who worked alongside their teachers on waste management projects voluntarily monitored the activities of their peers. One teacher explained "... students will exhibit positive actions if they are taught values and benefits, and are involved in decisionmaking" (Teacher 3, Action project report, May 2016). The teachers' and students' actions represent positive outcomes of the EE course, and highlight how ESD competences such as collaboration and action orientations were being developed.

Teacher 8, however, indicated difficulty in getting full class participation as only 20 of 36 students (55\%) willingly participated (Action project report, May 2016). Other teachers stressed the need for 'buy-in' from stakeholders. For instance, Teacher 3, with reference to her school administrators wrote "If you could NOT get others to see your ideas as sound and valid then it would be an uphill battle to implement the plan" (Action project report, May 2016). Overall, Teacher 6 supported the value of PjBL by stating her intention to use it as an assessment method "... with the aim of addressing my students attitudes/values ..." (Postcourse reflection document, May 2016).

Both positive and challenging experiences were reported by the teachers regarding implementation of their projects. However, feedback obtained from the project participants indicated evidence of some sustainability competencies such as motivation and commitment. ESD competencies were also evident through teachers' pedagogical approaches that encouraged integration of environmental sustainability issues into classroom discussions and promoted action-oriented activities that sometimes extended to contexts beyond the classroom.

\section{Case Two: Project-based learning with younger learners - TrashedWorld}

\section{Context}

TrashedWorld, a web-based platform hosted in Bulgaria, was constructed based on a documentary film Trash (https://blenheimfilms.com/trashed-no-place-for-waste/) that investigates the global impact of modern consumerism on pollution. The platform was conceptualised recognising the role of education in engaging young students on environmental and sustainability issues. Two major aims of the platform are to develop awareness of waste issues and improve communication among users. Content and language integrated learning is the disciplinary specialisation of one of designers (also an author of this paper) thus a core focus skill is improving communication while dealing with environmental issues. An intercultural communication framework (Schoen, Weisheit \& Kelly, 2011) guided the development of the materials for the website.

There are four modules in the programme, each focusing on one waste issue presented in the Trash documentary. Each lesson in the module includes a glossary, vocabulary, comprehension activities and concludes with an 'investigation', a project-based activity where students explore a waste issue in their schools or community. 


\section{Outcomes}

The platform was piloted, then launched in June 2016. Teachers registered their school then accessed the resources on the platform. After interacting with the content and activities in the modules, the students devised their investigation and implemented it in their schools or communities. The students recorded their results and experiences in various forms (e.g., videos, PowerPoint presentations, investigation report sheets). These artefacts were uploaded to the website by their teachers for access by peers globally. The teachers gave feedback about the platform through the website and other social media applications (e.g. Google Groups(C). The investigation reports and artefacts indicated that students collected data through forms such as questionnaires and interviews administered to community members (e.g., shopkeepers, waste facility managers). The reports and artefacts of the students from Slovenia, Bulgaria and Italy were analysed to provide insight into students' activities.

In Slovenia, some students investigated waste management in their communities and produced a PowerPoint presentation entitled the 'Circle of Trash'. Here they identified various types of community waste and considered how they were discarded. From their investigation they concluded waste management efforts in their community were effective.

Bulgarian students reported on a 'waste clean-up campaign' in their community by creating news posters which were displayed at their school. The students reported a sense of ownership of the project due to their close involvement in it. For example, one student wrote about waste observed in her community: "The trash is there because of US! It is our responsibility to clean it. We must try to keep our town for the future generations."

In Italy, after watching the documentary clips, students implemented various projects in their school, home and community. One project involved waste separation in their homes and tracked how much waste was generated. They reported: "We produced about 10 kilos of glass during a week, about 2 kilos of paper and 15 kilos of plastic". In another project, the students compared grocery store packaging in their city with examples in the film, and reported that the dimensions were similar to those recommended in the film.

The students applied critical thinking competencies to knowledge gained about the state of waste in their specific country, city and community. For example, in referring to their community, one group wrote "... half of the inhabitants use bins so the town is very dirty ... in the city centre on the floor there is scrap paper, chewing gum or cigarette butts". Students started to form opinions about the habits of residents. According to one report, “... sometimes we find some plastic wraps or some cans on the ground because some people don't care very much about the environment ...". Another report stated: "We think many people don't use bins because they don't care a lot about the environment. Others, instead, know how much this can help the planet, so they use them ... Also, a lot of people don't recycle, because they simply don't know the consequences". Through the platform these learners communicated with their peers locally and in other countries about the environmental issues. Comparisons made with environmental issues globally support competency in self-awareness. 


\section{Discussion}

Descriptions of two cases were provided in this paper of how PjBL can foster ESD competencies and promote environmental sustainability actions. In Case One, PjBL was used as a summative assessment tool, but supported formatively throughout the course in the form of class discussions. With respect to Case Two, project formulation and implementation supported classroom teaching. The data suggests that some ESD competencies were evident in the participants' actions namely: strategic competencies (the participants devised and implemented projects in their local contexts dealing with local environmental issues and in Case Two, these were shared globally), collaborative competencies (participants worked with internal and external partners such as students, school personnel and community members to complete projects), critical thinking (authentic environmental problems were identified which challenged personal practices and behaviours; participants reflected on practices and observations) and integrated problem-solving (solutions were proposed for environmental and sustainability issues).

The ESD competencies observed can be explained by the action-oriented approach and authentic contexts provided by PjBL - TrashedWorld provided opportunities to do this within an intercultural context. By 'learning to do' (UNECE, 2011; Efstratia, 2014), participants gained new knowledge (e.g., about solid waste pollution, electricity and water consumption patterns), confidence (e.g., gathering and interpreting empirical data, convening meetings, conducting interviews), problem-solving skills, and increased motivation (e.g., being inspired to address issues such as deforestation) (Bell, 2010; Genc, 2014; Rieckmann, 2018).

The online platform allowed students to be active global citizens, positioned them as change agents and provided an avenue for sharing the results with local and global communities, thus supporting the development of communication competencies. The online platform was relevant for supporting PjBL as a tool for giving students from different cultures and contexts a global voice about environmental issues (Larmer \& Mergendoller, 2010).

One challenge identified in $\mathrm{PjBL}$ in this study was obtaining support from collaborators, also reported by Aitken (2019). Teachers in Case Two felt that more time was needed for supervising projects. The latter would pose an even greater challenge for teachers operating in exam-driven contexts such as in the Caribbean, who have long contended with the pressure of completing curricula (David, 2008).

In comparing the two cases, we learnt that environmental issues such as solid waste management are similar in both cultures which necessitated real-world problem solving, and PjBL facilitated this. We noted that young people were at the heart of the engagement directly (Bulgaria) and indirectly (Jamaica - through capacity building of teachers who then translated this into their classroom practices). In Bulgaria there was one large project and issue around which youth action coalesced, whilst in Jamaica there were various projects around various issues amongst teachers. The specific differences in our approaches to $\mathrm{PjBL}$ implementation could have been influenced by cultural factors. This suggests that in applying $\mathrm{PjBL}$, one should consider the specific cultural context as this may influence how the strategy is implemented. 


\section{Conclusions and recommendations}

Project-based learning is relevant in facilitating ESD competencies. It centralises teachers' and students' learning experiences to enhance various skills and competencies related to environmental and sustainability actions in different cultural contexts. These include collaboration, critical thinking, strategic competencies, self-awareness and communication, all of which are necessary to address the local and global challenges facing the $21^{\text {st }}$ century world. Project-based learning takes varied formats and can be implemented in formal and nonformal settings. In both cases shared in this paper, authentic issues were addressed through a collaborative, problem-solving approach in a project-related context that connected adult and young learners with various stakeholders within their educational institutions and their communities.

We support the recommendation for $\mathrm{PjBL}$ to be a part of teacher-preparation and professional development programmes to provide real-world experiences, and develop teachers' ESD competencies (and to encourage others) to become change agents. School administrators should encourage a culture to support curriculum activities that infuse $\mathrm{PjBL}$, and enable teachers' collaborative efforts on projects so it does not feel like 'added work'. Mentors and experts outside of the formal education system could collaborate to provide project design and implementation support for teachers and students.

We are not aware of any study which focused on PjBL and ESD competencies in our country contexts, thus this paper adds to the body of literature and contributes to this gap. We recommend in future more research to provide cases showing how PjBL can be infused in teaching to support ESD for effecting sustainability action, and also to target specific competencies. Future research can also focus on which competency framework/s may be suited for specific cultural contexts.

In conclusion, PjBL transcends disciplines and cultures. It is a valuable teaching-learning strategy that supports environmental learning, fosters ESD competencies and can close the gap between environmental and sustainability knowledge and action.

\section{Notes on the contributors and their contributions}

\section{Lead author}

Bramwell-Lalor, Sharon

Sharon Bramwell-Lalor is a lecturer in Science Education in the School of Education at The University of the West Indies, Mona, Jamaica, and a member of the Education for Sustainable Development Working Group.

\section{Co-author}

Kelly, Keith

Keith Kelly is a consultant in Content and Language Integrated Learning (CLIL). He is foundercoordinator of Forum for Across the Curriculum Teaching, and co-creator of TrashedWorld and Putting CLIL into Practice, all web-based platforms. 


\section{Co-author}

\section{Ferguson, Therese}

Therese Ferguson is a lecturer in Education for Sustainable Development (ESD) in the School of Education (SOE) at The University of the West Indies, Jamaica, and Coordinator of the SOE's ESD Working Group.

\section{Co-author}

\section{Hordatt Gentles, Carol}

Carol Hordatt Gentles is a senior lecturer in Teacher Education and Teacher Development in the School of Education (SOE) at The University of the West Indies, Jamaica, and a member of the SOE's Education for Sustainable Development Working Group.

\section{Co-author}

\section{Roofe, Carmel}

Carmel Roofe is a senior lecturer in Curriculum and Instruction in the School of Education, Tthe University of the West Indies, and a member of the Education for Sustainable Development (ESD) Working Group.

\section{Percentage contribution}

\begin{tabular}{|l|l|c|}
\hline \multirow{4}{*}{ Areas of contribution } & Author & $\begin{array}{c}\text { Percentage } \\
\text { contribution }\end{array}$ \\
\hline \multirow{4}{*}{$\begin{array}{l}\text { Conception or design of the paper, theory or } \\
\text { key argument }\end{array}$} & Bramwell-Lalor & $20 \%$ \\
\cline { 2 - 3 } & Kelly & $20 \%$ \\
\cline { 2 - 3 } & Ferguson & $20 \%$ \\
\cline { 2 - 3 } & Hordatt Gentles & $20 \%$ \\
\cline { 2 - 3 } & Roofe & $20 \%$ \\
\hline \multirow{5}{*}{ Data collection } & Bramwell-Lalor & $20 \%$ \\
\cline { 2 - 3 } & Kelly & $20 \%$ \\
\cline { 2 - 3 } & Ferguson & $20 \%$ \\
\cline { 2 - 3 } & Hordatt Gentles & $20 \%$ \\
\cline { 2 - 3 } & Roofe & \\
\hline
\end{tabular}




\begin{tabular}{|l|l|c|}
\hline \multirow{4}{*}{ Areas of contribution } & Author & $\begin{array}{c}\text { Percentage } \\
\text { contribution }\end{array}$ \\
\hline \multirow{4}{*}{ Analysis and interpretation } & Bramwell-Lalor & $20 \%$ \\
\cline { 2 - 3 } & Kelly & $20 \%$ \\
\cline { 2 - 3 } & Ferguson & $20 \%$ \\
\cline { 2 - 3 } & Hordatt Gentles & $20 \%$ \\
\cline { 2 - 3 } & Roofe & $20 \%$ \\
\hline \multirow{5}{*}{ Drafting the paper } & Bramwell-Lalor & $20 \%$ \\
\cline { 2 - 3 } & Kelly & $20 \%$ \\
\cline { 2 - 3 } & Ferguson & $20 \%$ \\
\cline { 2 - 3 } & Hordatt Gentles & $20 \%$ \\
\cline { 2 - 3 } & Roofe & \\
\hline
\end{tabular}

\section{References}

Aitken, L. (2019, May). Teacher perspectives on using project-based learning. Teacher.

Retrieved from https://www.teachermagazine.com.au/articles/teacher-perspectives-onusing-project based-learning

Australian Public Service Commission. (2007). Tackling wicked problems: A public policy perspective. Canberra: Australian Public Service Commission.

Bell, S. (2010). Project-based learning for the $21^{\text {st }}$ century: Skills for the future. The Clearing House, 83, 39-43.

Buckles, J. (2018). Education, sustainability and the ecological imaginary: Connective education and global change. Cham: Palgrave Macmillan.

Cloud, J. (2014). The essential elements of education for sustainability (EfS). Journal of Sustainability Education, 6. Retrieved from http://www.jsedimensions.org/wordpress/wpcontent/uploads/2014/05/Cloud-Jaimie-JSE-May-2014-PDF-Ready2.pdf

David, J.L. (2008). What research says about ... /Project-Based learning. Leadership, 65(5), 80-82. http://www.ascd.org/publications/educational_leadership/feb08/vol65/num05/ Project-Based_Learning.aspx

De Haan, G. (2006). The BLK '21' programme in Germany: A 'Gestaltungskompetenz'- based model for education for sustainable development. Environmental Education Research, 1, 19-32.

Duerden, M.D. \& Witt, P.A. (2010). The impact of direct and indirect experiences on the development of environmental knowledge, attitudes, and behavior. Journal of Environmental Psychology, 30(4), 379-392.

Efstratia, D. (2014). Experiential education through project based learning. ProcediaSocial and Behavioral Sciences. doi: 10.1016/j.sbspro.2014.09.362. 
English, M.C. \& Kitsantas, A. (2013). Supporting student self-regulated learning in problemand project-based learning. Interdisciplinary Journal of Problem-Based Learning, 7(2), 128-150.

Genc, M. (2014). The project-based learning approach in environmental education. International Research in Geographical and Environmental Education, 24(2), 105-111.

Gomm, R., Hammersley, M. \& Foster, P. (2000). Case study method: Key issues, key texts. Thousand Oaks: Sage.

Gough, A. (May, 2006). Working at the margins of sustainability: Implementing ESD in Victorian government schools. Paper presented at the University of Bath Centre for Research in Education and the Environment, England.

Hume, T. \& Barry, J. (2015). Environmental education and education for sustainable development. In J. Wright (Ed), International Encyclopedia of the Social and Behavioural Sciences. Amsterdam: Elsevier. pp.733-739.

Jones, C., \& Akura, G. (2017). Addressing the 'wicked problems' of sustainability through consciousness-based education. Journal of Maharishi Vedic Research Institute, 4, 75-122.

Kilinç, A. (2010). Can project-based learning close the gap? Turkish student teachers and proenvironmental behaviours. International Journal of Environmental and Science Education, 5(4), 495-509.

Krasny, M. (2013). Introduction. Tales of a transdisciplinary scholar. In M.E. Krasny \& J. Dillon (Eds). Trading Zones in Environmental Education: Creating transdisciplinary dialogue. New York: Peter Lang. pp. ix-xx.

Lambrechts, W., Mulà, I., Ceulemans, K., Molderez, I. \& Gaeremynck, V. (2013). The integration of competences for sustainable development in higher education: An analysis of bachelor programs in management. Journal of Cleaner Production, 48, 65-73.

Larmer, J. \& Mergendoller, J.R. (2010). Seven essentials for project-based learning. Educational Leadership, 68(1), 34-37.

Laurie, R., Nonoyama-Tarumi, Y., Mckeown, R. \& Hopkins, C. (2016). Contributions of Education for Sustainable Development (ESD) to quality education: A synthesis of research. Journal of Education for Sustainable Development, 10(2), 226-242.

Leicht, A., Combes, B., Byun, W.J. \& Agbedahin, A.V. (2018). From Agenda 21 to Target 4.7: The development of ESD. In A. Leicht, J. Heiss, \& W.J. Byun (Eds.). Issues and Trends in Education for Sustainable Development. Paris: UNESCO. pp. 25-38.

Lozano, R., Ceulemans, K., Alonso-Almeida, M., Huisingh, D., Lozano, F.J., Waas, T., Lambrechts, W., Lukman, R. \& Hugé, J. (2015). A review of commitment and implementation of sustainable development in higher education: Results from a worldwide survey. Journal of Cleaner Production, 108, 1-18.

Malek, N.P., Hall, J.C. \& Hodges, C. (2014). A review and analysis of the effectiveness of alternative teaching methods on student learning in economics. Hodges Perspectives on Economic Education Research, 9(1), 75-85.

McKeown, R. \& Hopkins, C. (2003). EE $\neq$ ESD: Defusing the worry. Environmental Education Research, 9(1), 117-128. 
Rieckmann, M. (2018). Learning to transform the world: Key competencies in Education for Sustainable Development. In A. Leicht, J. Heiss \& W.J. Byun (Eds.). Issues and Trends in Education for Sustainable Development. Paris: UNESCO. pp. 39-59.

Roessingh, H. \& Chambers, W. (2011). Project-based learning and pedagogy in teacher preparation: Staking out the theoretical middle ground. International Journal of Teaching and Learning in Higher Education, 23(1), 60-71.

Saavedra, A.R. \& Opfer, V.D. (2012). Learning 21st-Century skills requires 21st-Century teaching. Phi Delta Kappan, 94(2), 8-13.

Schoen, L., Weisheit, E. \& Kelly, K. (2011, July-August). Communicating chemistry. Chemistry International News Magazine, 33(4), 3-5.

Scott, C.L. (2015). The futures of learning: What kind of pedagogies for the 21st century? UNESCO Education Research and Foresight, Paris. ERF Working Paper Series, No. 15.

Sleurs, W. (2008). Competencies for ESD (Education for Sustainable Development) teachers: A framework to integrate ESD in the curriculum of teacher training institutes. Comenius 2.1 project 118277-CP-1-2004-BE-Comenius-C2.1. Retrieved from https://www.platform. ue4sd.eu/downloads/CSCT_Handbook_11_01_08.pdf

Stefanou, C., Stolk, J., Prince, M., Chen, J. \& Lord, S. (2013). Self-regulation and autonomy in problem- and project-based learning environments. Active Learning in Higher Education, 14, 109-122.

Tamim, S.R., \& Grant, M.M. (2013). Definitions and uses: Case study of teachers implementing project-based learning. Interdisciplinary Journal of Problem-Based Learning, 7(2), 72-101.

UNECE (United Nations Economic Commission for Europe). (2005). UNECE strategy for education for sustainable development. United Nations Economic Commission for Europe, Geneva. Retrieved from https://www.edu.ro/sites/default/files/Strategia\%20 UNECE\% 20pentru\%20EDD_versiunea\%20in\%20lb.\%20engleza.pdf

UNECE (United Nations Economic Commission for Europe). (2011). Learning for the Future: Competences in Education for Sustainable Development. Geneva: United Nations Economic Commission for Europe.

UNESCO (United Nations Educational, Scientific, and Cultural Organization). (2014). UNESCO Roadmap for Implementing the Global Action Programme on Education for Sustainable Development. Paris: UNESCO.

Wiek, A., Withycombe, L. \& Redman, C. (2011). Key competencies in sustainability: A reference framework for academic program development. Sustainability Science, 6, 203- 218.

Wiek, A., Bernstein, M., Foley, R., Cohen, M., Forrest, N., Kuzdas, C., Kay, B. \& Withycombe Keeler, L. (2016). Operationalising competencies in higher education for sustainable development. In M. Barth, G. Michelsen, M. Rieckmann \& I. Thomas (Eds). Handbook of Higher Education for Sustainable Development. London: Routledge. pp. 241-260.

Wright, M. F., \& Monsour, F. A. (2020). Sustainability education assessments in teacher education: Addressing 'wicked problems' in a postmodern world. In J.O. Michel (Ed). Teaching and Learning about Sustainability in Higher Education. Hoboken: Wiley. pp. 155-176. 
